\title{
KERUSAKAN LINGKUNGAN: \\ EPISTEMOLOGI SAINS ISLAM DAN TANGGUNG JAWAB MANUSIA
}

\section{Fachruddin Mangunjaya}

Pusat Pengkajian Islam (PPI) Universitas Nasional

Jl Sawo Manila No 61, Pejaten, Ps Minggu, Jakarta Selatan 12520

e-mail: fmangunjaya@civitas.unas.ac.id

\begin{abstract}
This article examines the challenges of environmental degradation and arguing to retun back to the Quran as a search of epistemological foundation of science and a necessary strong foundation in managing the balance of carrying for the earth and environmental crisis. This study also explores the principles of Islamic in view of the environmental approach such as the understanding keywords about the God creation (Ilm-al-Khalq), which can be laid as foundations such as tawhild, which encourage the belief that the only the Creator with all power single, the khalifah (caliph) that empasis on man responsibility, mīzān which refers to maintaining a balance and keeping the fitrah as ordered of (human) nature in order to maintain the patterns of life and the integrity of God's creation.
\end{abstract}

Abstrak: Artikel ini menguji tantangan-tantangan degradasi lingkungan dan mengajukan pendapat untuk kembali kepada al-Quran sebagai sebuah cara mencari dasar epistemologi sains dan sebuah dasar yang kuat dalam mengelola keseimbangan bagi bumi dan krisis lingkungan. Studi ini mengeksplorasi prinsip-prinsip Islam dalam memandang terhadap pendekatan lingkungan seperti adanya pemahaman kata-kata kunci tentang ciptaan Tuhan ('Ilm al-Khalq), yang bisa ditempatkan sebagai dasar-dasar, yang mendorong keimanan sehingga hanya ada Sang Pencipta dengan kekuatan yang tunggal, sang khalifah yang menekankan pada tanggung jawab manusia, mīzān yang merujuk pada mempertahankan keseimbangan pola-pola kehidupan dan integritas makhluk Tuhan.

Keywords: Islamic epistemology, science, lingkungan, khalīfah, mìzān. 


\section{A. Pendahuluan}

Albert Einstein, menulis surat tentang keyakinannya pada Agama yang akan dapat menjadi penopang keberhasilan ilmu pengetahuan untuk kemanusiaan dan peradaban. ${ }^{1}$ Ketimpangan dan kerusakan lingkungan yang terjadi sekarang ini, merupakan akibat jauhnya ilmu pengetahuan pada kaidah-kaidah agama yang dapat melakukan rem dan mencegah adanya "kelumpuhan" mendalam pada peradaban manusia, akibat sains yang meninggalkan agama. Berbagai kerusakan lingkungan yang kerap mengakibatkan bencana, bisa kita saksikan menjadi meningkat frekuensinya, tentulah diakibatkan tingginya laju perusakan akibat agama telah ditinggalkan sebagai norma etika dan juga kebaikan akhlak.

Sains dan aplikasi teknologi yang tidak dibungkus dengan kerangka agama ini menimbulkan perilaku hedonis hanya mencari kepuasan materi yang tidak berujung pangkal, tidak lagi memikirkan dampak dan telah melanggar etika dan kepantasan dan melanggar empati kemanusiaan. Oleh karena itulah, ilmu pengetahuan yang berintegrasi dengan pemahaman agama akan memegang posisi penting. Prinsip prinsip agama sudah semestinya menjadi pilar dalam memperkaya integritas sebagai ilmuwan Islam bukan saja dari tataran filosofis tetapi harusnya sampai pada tingkat kebijakan dan sikap praksis.

\footnotetext{
${ }^{1}$ Childish superstition: Einstein's letter makes view of religion relatively clear. http://www.theguardian.com/science/2008/m ay/12/peopleinscience.religion
}

Bagi seorang Muslim sudah sepantasnya sangat bersyukur karena Kitab Sucinya (al-Quran) adalah Mukjizat. Kesucian al-Quran inilah yang seharusnya menjadi fondasi yang penting bagi pengembangan pengetahuan. Sudah seharusnya umat Islam memandang pengetahuan yang diperolehnya tanpa adanya pandangan dikhotomis antara pengetahuan dan agama. Mengapa? Sebab, al-Quran merupakan kitab petunjuk bagi manusia, penjelasan atas petunjuk tersebut dan pembeda antara haq dan batil (QS. al-Baqarah [2]: 185).

Setelah hampir 15 Abad, al-Quran diturunkan, ia merupakan satu-satunya wahyu yang teruji dan dapat membuktikan mukjizatnya, banyak di antaranya hanya dapat dimengerti setelah penemuan demi penemuan sains dibuktikan di zaman modern, abad XX ini. Maurice Buchaille, seorang ahli bedah menguraikan tentang mukjizat alQuran yang tidak terbantahkan, Wikipedia menuliskan:

"Buchaille mengatakan bahwa Islam, sains dan agama adalah merupakan "sudara kembar". Menurutnya terdapat kesalahan monumental pada Bibel namun tak ada satupun kesalahan al-Quran yang ditinjau dengan pengetahuan modern. Bucaille yakin bahwa deskripsi al-Quran tentang fenomena alam sangat kompatibel dengan sains modern."2

Al-Quran juga mampu menjadi "futurist" meramalkan kejadian masa depan dan kini menjadi sejarah. Sejarah penaklukan Bizantium (Romawi Timur) yang merupakan negara Adidaya atau

2 Wikipedia.org/wiki/Maurice_Bucaille 
Super Power abad pertengahan (1453 M), sudah diramalkan oleh Surat alRūm [30]: 1-2, dan juga diramalkan oleh hadis Rasulullah saw:

"Konstantinopel akan jatuh ke tangan Islam. Pemimpin yang menaklukkannya adalah sebaik-baik pemimpin dan pasukan yang berada di bawah komandonya adalah sebaik-baik pasukan." [H.R. Ahmad bin Hanbal AlMusnad 4/335]

Maka, sesungguhnya umat Islam mempunyai pedoman atau petunjuk yang jelas, bukan saja harus diyakini, tetapi dapat menjadi landasan mencari ilmu (epistemologi), sehingga kebenaran al-Quran inilah yang dapat menjadi cahaya manusia dan ilmuwan muslim ditengah kegelapan dan kegalauan.

Keunggulan al-Quran yang lain adalah klaim bahwa apa yang di langit dan di bumi juga merupakan ayat-ayat bagi orang yang mempunyai akal (QS. Ali Imran [3]: 190).

Sesungguhnya dalam penciptaan langit dan bumi, dan silih bergantinya malam dan siang terdapat tandatanda bagi orang-orang yang berakal, (yaitu) orang-orang yang mengingat Allah sambil berdiri atau duduk atau dalam keadaan berbaring dan mereka memikirkan tentang penciptaan langit dan bumi (seraya berkata): "Ya Tuhan kami, tiadalah Engkau menciptakan ini dengan sia-sia. Maha Suci Engkau, maka peliharalah kami dari siksa neraka. (QS. Ali Imran [3]: 190-191).

Ibn Kasīr menggarisbawahi yang dimaksud dengan ciptaan Allah itu adalah:

“...merujuk pada pada langit yang tinggi hamparan bumi yang luas hamparan, planet yang mengelilingi matahari padang pasir, pohon, tanaman, buah-buahan, binatang, logam dan berbagai warna menguntungkan, aroma, rasa dan elemen. (Ayat ...dan memikirkan tentang penciptaan langit dan bumi), merenungkan tentang tanda tanda yang ada di langit da bumi serta menjadi tanda kebesaran, kemahaperkasaan, ilmu pengetahuan, kasih sayang dan kearifan Allah. Allah mengkritik mereka yang tidak merenungkan tentang ciptaan-Nya, yang membuktikan keberadaan-Nya, Atribut, Syari`ah, keputusan-Nya dan Ayat: 'Dan banyak sekali tanda-tanda (kekuasaan Allah) di langit dan di bumi yang mereka melaluinya, sedang mereka berpaling daripadanya. Dan sebahagian besar dari mereka tidak beriman kepada Allah, melainkan dalam keadaan mempersekutukan Allah (dengan sembahan-sembahan lain). (QS. Yūsuf [12]: 105-106).'”3

Sangat jelas, dan nyata bahwa mufasir Ibn Kasīr pun sepakat bahwa ciptaan-langit, bumi dan segala isinya-merupakan tanda-tanda kekuasaan Allah seperti yang nyata dijumpai di muka bumi tempatnya manusia dan makhluk lainnya, bukan yang selain itu. Jadi apabila bumi sebagai ciptaan-Nya menjadi rusak dan menimbulkan banyak bencana, maka semua itu merupakan suatu sunnah Allah akibat dari kelalaian manusia. Sudah saatnya pula, ilmuwan Muslim untuk kembali tetap berpedoman pada keunggulan al-Quran.

3Ibn Kasīir, Tafsir Ibnu Katsir, Jil. II, terj. M. Abdul Ghoffar E.M, Jakarta: Pustaka Imam asy-Sayfi'I, 2001, h. 209-210. 


\section{B. Kerusakan Lingkungan}

Lingkungan memang tengah mengalami kerusakan, kekhawatiran atas kerusakan tersebut, telah diakui adalah akibat ketidak seimbangan yang terjadi dan disebabkan intervensi manusia yang berlebihan. Kerusakan lingkungan ini mendorong para pemimpin dunia megadakan pertemuan puncak (Konferensi Tingkat Tinggi-KTT) tahun 1992 di Rio de Janeiro, Brasil untuk membicarakan bagaimana nasib planet bumi dimasa depan. Saat pertemuan puncak Perserikatan BangsaBangsa (PBB) setelah (KTT Bumi) tahun 1992, maka disepakatilah tiga konvensi penting yang mengikat berbagai bangsabangsa di muka bumi untuk dapat melakukan sesuatu bagi keselamatan planet ini,

Peraturan tersebut diataranya adalah: (1). Konvensi PBB Tentang Perubahan Iklim (UNFCCC); (2). Konvensi PBB tentang Keanekaragaman Hayati (UNCBD) dan (3). Konvensi mencegah terjadinya penggurunan (UNCCD). Tiga jenis konvensi tersebut menjadi berkekuatan hukum, manakala masing-masing negara melakukan ratifikasi (mengadopsi) menjadi undang-undang di negara masingmasing. Dari ketiga konvensi tersebut, maka dua konvensi yaitu UNCBD dan UNFCCC merupakan peraturan lingkungan dunia yang mengikat dan paling sering di rundingkan. Sekarang ini November hingga Desember 2013 sedang diadakan negosiasi tentang perubahan iklim Conference of Parties (COP)-19/CMP-9 yang dikuti oleh negara anggota penanda tangan konvensi tersebut di Warsawa, Polandia. Sedangkan UNCBD akan mengadakan negosiasi COP-12 pada tahun $2014 \mathrm{di}$ Korea.

Adapun UNFCC mempunyai tujuan agar semua bangsa dapat mengurangi pencemaran atmosfer dari gas-gas rumah kaca (GRK). Terdapat enam jenis Gas Rumah Kaca (GRK) yang dapat menimbulkan pemanasan global dan dibicarakan di UNFCCC adalah: karbon dioksida $\left(\mathrm{CO}_{2}\right)$, metan $\left(\mathrm{CH}_{4}\right)$, nitrat oksida $\left(\mathrm{N}_{2} \mathrm{O}\right)$, dan gas-gas yang mengandung fluor, seperti hydroflourocarbon (HFCs), perfluorocarbon (PFCs), dan sulphur hexafluorida ( $\left.\mathrm{SF}_{6}\right)$. Dari keenam gas-gas rumah kaca tersebut, karbon dioksida mengambil porsi terbesar, yaitu sekitar 75\%. Oleh karena itulah, jumlah GRK selalu disetarakan dengan kandungan $\mathrm{CO}_{2}$ yang ada di atmosfer.

Perubahan iklim ini selalu dimonitor secara ilmiah oleh ribuan ilmuan dari lintas negara, berdasarkan laporan ilmiah yang disebut Assasement Report (AR) tim ahli PBB yang tergabung dalam Intergovemental Panel on Climate Change (IPCC), memberikan laporan teknis kepada PBB dan publik akan adanya perubahan iklim global. Terakhir, IPPC membuat laporan ke 4, pada tahun 2007, yang disebut juga Assessment Report (AR) 4, laporan ini direview oleh 6000 ilmuwan di seluruh dunia, sehingga menjadi salah satu dokumen dengan pengakuan ilmu pengetahuan yang valid dan tinggi. Dalam AR 4, IPCC menyimpulkan:

"pemanasan sistem iklim adalah nyata", dan "sebagian besar peningkatan suhu rata-rata global yang diamati sejak pertengahan abad ke-20 sangat mungkin diakibatkan oleh peningkatan konsentrasi gas rumah 
kaca yang diakibatkan oleh manusia (antropogenik).4"

Akibat dari pemanasan global, maka timbul perubahan iklim yang wujudnya berupa anomali cuaca dan penyimpangan-penyimpangan musim yang sulit diprediksi. Ritme keseimbangan alam menjadi terganggu, disebabkan emisi gas-gas rumah kaca yang kian menumpuk di atmosfer. Daniel Murdiyarso, peneliti senior pada Centre for International Forestry Reseacrh (CIFOR) dan Guru Besar Ilmu Atmosfer, Institut Pertanian Bogor (IPB) menuliskan, "Karena iklim juga menjadi suatu ciri fisik suatu kawasan, maka jika terjadi perubahan, dampaknya terhadap komponen-komponen biotik (hidup) dan abiotik (tak hidup) akan sangat luas. Boleh jadi, perubahan itu bersifat permanen karena hilangnya komponen penting dalam kawasan, misalnya hutan sebagai ekosistem atau spesies yang ada di dalam ekosistem hutan tersebut." 5 Oleh karena itu, dampak perubahan iklim dianggap sangat fatal dan mengerikan, karena manusia tidak bisa mengembalikan (irreversible), apabila iklim berubah.

Apabila diperhatikan, perubahan iklim ini terjadi nyata setelah adanya revolusi Industri pada abad 17 dan 18,

4 "...warming of the climate system is unequivocal", and "most of the observed increase in global average temperatures since the mid-20th century is very likely due to the observed increase in anthropogenic greenhouse gas concentrations." IPCC Report AR4. IPCC Fourth Assessment Report: Climate Change 2007. The Physical Science Basis, artikel diakses dari http://www.ipcc.ch/publications_and_data/ar4/ wg1/en/spmsspm-direct-observations.

${ }^{5}$ D. Murdiarso, "Perubahan Iklim: Dari Obrola Warung Kopi ke Meja Perundingan", Prisma, April 2012, h. 23-33. sebagai dampak dari majunya ilmu pengetahuan dan teknologi yang berkiblat pada ekonomi kapitalistik dan eksploitas sumber daya alam yang sangat masif. Sayangnya dari laporan terakhir, tidak ada upaya signifikan pengurangan konsertrasi gas-gas rumah kaca yang terus menumpuk di atmosfer.

Ancaman perubahan iklim sesungguhnya sangat mengerikan, Bank Dunia (2012), memberikan gambaran, bahwa jika kita (warga bumi) tetap tidak melakukan tindakan apa-apa atau business as usual (BAU) maka akan terjadi peningkatan suhu hingga $4^{\circ} \mathrm{C}$, dan hal ini akan mengakibatkan dampak yang mengerikan: kota-kota pesisir terancam banjir, produksi pangan terancam turun yang tentu saja akan meningkatkan kasus malnutrisi disebabkan banyak kawasan kering yang akan semakin kering, dan kawasan basah menjadi lebih basah.

\section{Kritik Filsafat Lingkungan pada Keyakinan Agama}

Kepentingan terhadap kondisi planet bumi yang stabil, merupakan kebutuhan semua makhluk, tidak terkecuali manusia. Perubahan iklim membawa krisis lingkungan dan ketidak stabilan yang massif akibat anomali cuaca dan musim yang tidak menentu. Dugaan besar terhadap seringnya terjadi prekwensi badai dan angin puting beliung, di beberapa tampat akhir-akhir ini, juga dipicu oleh adanya perubahan iklim. Tercatat prekwensi bagai dan gelombang laut semaking tinggi dan demikian pula musim kemarau panjang (el nino) dan musim monsun basah (la nina), semakin sering terjadi. 
Beberapa peristiwa banjir semakin sering dijumpai melebihi frekuensi bencana banjir tahun-tahun sebelumnya. Hal ini diakibatkan anomali iklim dan rusaknya keseimbangan dan berkurangnya kapasitas daya dukung bumi. Pertanyaan penting yang harus dijawab, adakah langkah kedepan yang dapat diambil dalam upaya menanggulangi krisis ligkungan ini? Mengapa krisis dan kerusakan lingkungan terjadi dan pengurasan terhadap dan tidak berhenti merongrong dan rupanya, menurut Lynn White Jr, persepsi pemahaman manusia, sangat bergantung dengan apa yang menjadi keyakinan mereka akan apa yang diajarkan oleh Agama.

"mentality of the Industrial Revolution, that the earth was a resource for human consumption, was much older than the actuality of machinery, and has its roots in medieval Christianity and attitudes towards nature...what people do about their ecology depends on what they think about themselves in relation to things in their environment. ${ }^{\prime \prime}$

Apa yang dikatakan oleh Lynn White, bahwa akar krisis terhadap lingkungan adalah bahwa mentalitas Revolusi Industri, yang menjadi jembatan pemahaman bahwa bumi adalah sumber daya untuk konsumsi manusia, jauh lebih tua dari aktualitas mesin, dan memiliki akar dalam Kekristenan abad pertengahan dan kemudian menentukan sikap para industrialis tersebut terhadap alam, dan

${ }^{6}$ Lynn White Jr, "The Historical Root of our ecologic crises", Science Vol 155 (Number 3767), 10 Maret 1967, h. 1203-1207. apa yang dilakukan orang tentang ekologi mereka tergantung pada apa yang mereka pikirkan tentang diri mereka sendiri dalam kaitannya dengan hal-hal di lingkungan mereka.

Hal senada dikemukakan oleh Seyyed Hossein Nasr, yang memiliki pemikiran yang lebih ekstrim tentang hubungan manusia dan tanggunjawab mereka terhadap alam:

"Nature has become desacralized for modern man Nature has come to be regarded as something to be used and enjoyed to the fullest extent possible....for modern man nature has become like a prostitute to be benefited from without any sense obligation and responsibility toward her"7

Jadi alam telah menjadi tidak suci lagi bagi manusia modern, dan apa yang menjadi karunia alam dan dianggap sebagai sesuatu yang harus digunakan dan dinikmati semaksimal mungkin Bagi manusia modern, alam hanya seperti seorang pelacur dimana manusia diuntungkan tanpa adanya kewajiban untuk ikut bertanggungjawab, merawatnya. Memikirkannya untuk generasi mendatang dan memikirkan keturunan yang lebih baik. Hal ini nyata terjadi, ketika konsesi diberikan, maka para investor dan pengusaha hanya merasa bertanggunjawab dan lunas kewajibannya, setelah membayar rente (iuran) hasil-hasil hutan atau perijinan yang diwajibkan pemerintah, tanpa mempunyai beban kemudian mereka dapat dengan mudahnya mengambil

${ }^{7}$ Seyyed Hossein Nasr, "The Problem," taken from Man and Nature, Chicago: Kazi Publication, 1997. 
keuntungan sementara bumi yang ditinggalkannya: berlobang, longsor, kehilangan sumber daya dan seterusnya.

Lebih dari itu, bagi banyak manusia ekonomi, maka tidak ada kehadiran Tuhan di dalam kerja mereka. Eksploitasi merupakan sebuah keniscayaan, keuntungan yang diperoleh memang diperuntukkan bagi kesejahteraan manusia. Sayangnya ternyata hanya jangka pendek. Jadi, dalam terjadi disintegrasi antara pesan-pesan agama dan kehendak manusia (yang serakah) dan kesenjagan terjadi pada arena seperti ini, seperti yang dikatakan oleh Nasr,

"The harmony between man and nature has been destroyed...but not everyone realized that this disequilibrium is due to the destruction of the harmony between man dan God."8

Kesimpulannya boleh jadi bahwa manusia kemudian telah tersesat menjauh dan merusak bumi, karena meninggalkan pesan-pesan agama dan menjauh dari keyakinan agama.

\section{Integrasi Konservasi Lingkungan dalam Ajaran Islam ${ }^{9}$}

Al-Quran yang memanifestasikan totalitas ini dengan demikian adalah sebuah panduan untuk transaksi hidup bagi umat manusia. Hal ini meletakkan dasar-dasar bagi segala kegiatan kita

${ }^{8} \mathrm{Ibid}$.

${ }^{9}$ Sub Bab ini merupakan replikasi bagian yang diambil dari karya penulis, Fachruddin Mangunjaya, "Islam and Natural Resources Management", dalam J.M. McKay (ed), Integration Religion Within Conservation: Islamic Belief and Sumatran Forest Management, UK: Darwin Initiative Case Study, Durrel Insitute of Conservation and Ecology University of Kent, 2013, h.11-20. dalam penciptaan. Pada satu tingkatan, hal ini berbicara tentang melestarikan tubuh dan jiwa dan hubungan kita dengan tatanan alamiah, pada tingkatan yang lain hal ini berbicara tentang komunitas makhluk-makhluk yang terbang dan merayap dan meloncatloncat dan berenang, dan dalam tingkatan yang lain lagi, yang dibicarakan adalah alam semesta, hutan, dan sungai. Inti ajaran dalam al-Quran yang berhubungan dengan hal ini dapat digambarkan sebagai 'Ilm al-Khalq (Pengetahuan tentang Penciptaan) yang sudah ada sebelum ilmu ekologi berkembang empat belas abad kemudian. ${ }^{10}$

Ajaran-ajaran tentang lingkungan menimbulkan suatu fleksibilitas dalam pendekatan, dan kita telah memilih untuk merepresentasikan mereka ke dalam empat prinsip utama berikut: Tauḥìd, Khalīfah, Mìzān, dan Fițrah. Prinsip-prinsip ini adalah tema-tema dalam al-Quran yang dapat ditelusuri untuk mendidik masyarakat dan meningkatkan kesadaran tentang pengelolaan sumber daya alam dan lingkungan. Seiring kita menelaah prinsip-prinsip ini, kita akan membahas keempatnya dalam konteks pesan universal tentang lingkungan dari alQuran, dengan menggunakan acuan dari pendapat para ilmuwan dan cendekiawan Islam.

\section{Tauhìd}

Tauhīd adalah sebuah elemen dari prinsip-prinsip ajaran Islam tentang lingkungan yang menyatakan bahwa keimanan kepada Allah adalah mutlak,

\footnotetext{
${ }^{10}$ Fazlun Khalid, Qur'an Creation and Conservation, Birmingham, UK: Islamic Foundation for Ecology and Environmental Sciences 1999.
} 
menjadikan Islam sebagai agama monoteistik. Tauhīd disebutkan dalam prinsip Islam tentang iman sebagai iman di hadapan Allah. Dengan mengakui tauhīd, kita mengakui bahwa Allah adalah Satu dan ciptaan-Nya juga memiliki ciri kesatuan, atau disatukan secara keseluruhan. Allah sebagai pencipta telah menciptakan sedemikian rupa ciptaan-Nya akan diperlakukan sebagai alat untuk menyembah Dia (QS. al-Māidah [5]: 56). Allah adalah alKhāliq (Pencipta) yang menciptakan langit dan bumi dan segala sesuatu di dalamnya (baca: QS. al-Hasyr [59]: 24).

Dengan mengakui tauhīd, umat Islam juga menyadari adanya harmoni umum dari pencipta dan bahwa terdapat hukum kosmik yang mengatur rotasi bumi, matahari, bulan, bintang, dan lain-lain, selama miliaran tahun tanpa mengalami insiden apapun. Selama miliaran tahun, bumi tidak pernah mengalami tabrakan dengan bulan, atau bulan dengan matahari. Tanpa perintah yang ditetapkan Tuhan, semua ini tidak akan terjadi, karena Dialah yang menentukan orbit untuk setiap benda langit tersebut:

"Dia-lah yang menjadikan matahari bersinar dan bulan bercahaya dan ditetapkan-Nya manzilah-manzilah (tempat-tempat) bagi perjalanan bulan itu, supaya kamu mengetahui bilangan tahun dan perhitungan (waktu). Allah tidak menciptakan yang demikian itu melainkan dengan hak. Dia menjelaskan tanda-tanda (kebesaran-Nya) kepada orang-orang yang mengetahui." (QS. Yūnus [10]: 5).

"Tidaklah mungkin bagi matahari mendapatkan bulan dan malampun tidak dapat mendahului siang. Dan masing-masing beredar pada garis edarnya." ( QS. Yā Sīn [36]: 40).

"Orang-orang yang mengingat Allah sambil berdiri atau duduk atau dalam keadan berbaring dan mereka memikirkan tentang penciptaan langit dan bumi (seraya berkata): "Ya Tuhan kami, tiadalah Engkau menciptakan ini dengan sia-sia, Maha Suci Engkau, maka peliharalah kami dari siksa neraka." (QS Ali Imran [3]: 191).

Osman Bakar menyatakan bahwa memiliki nurani tentang Keesaan Allah berarti menegakkan kebenaran bahwa Allah adalah Satu dalam Zat-Nya, dalam nama-Nya, serta dalam sifat dan tindakan-Nya. Bakar sangat menegaskan definisi Tawhid sebagai sumber dan manifestasi dari semangat ilmu pengetahuan dalam Islam. Sebuah konsekuensi penting dari penegasan kebenaran sentral adalah masyarakat harus merangkul realitas objektif dari kesatuan alam semesta. Sebagai sumber untuk pengetahuan, agama menegaskan bahwa sesuatu yang ada di alam semesta ini saling berhubungan melalui hukum kosmis yang mengaturnya, dalam jaringan kesatuan alam semesta. Kosmos terdiri dari berbagai lapisan realitas, tidak hanya secara fisik. Tetapi hal ini menciptakan suatu asal mula metafisika terpadu yang dalam agama disebut sebagai Tuhan. ${ }^{11}$

Al-Quran juga menekankan bahwa kesatuan kosmis adalah contoh yang sangat baik dari sifat Tuhan yang Esa:

${ }^{11}$ Osman Bakar, Tauhid dan Sains: Esaiesai tentang Sejarah dan Filsafat Sains Islam, terj. Yuliani Liputo, Bandung: Pustaka Hidayah, 1994, h. 21. 
"Mereka selalu bertasbih malam dan siang tiada henti-hentinya." (QS. alAnbiyā [21]: 20).

Dalam sudut pandang Islam, tidak terdapat perbedaan antara yang hidup dan yang mati, karena semuanya adalah bagian dari ciptaan dan mereka tetap bertasbih kepada Allah (baca: QS. al-Isrā [17]: 44, al-Nūr [24]: 41, al-Anbiyā' [21]: 79). Semua makhluk dan ciptaan Allah bertasbih kepada-Nya (QS. al-Taghābun [64]: 1), yang juga merupakan ibadah mereka kepada Allah, tetapi tidak semua manusia memahaminya (QS. al-Isrā [17]: 44). Hal ini juga merefleksikan keesaan (tauhīd), di mana penciptaan alam dan manusia mempunyai tujuan yang sama. Oleh karena itu, esensi tauhīd dapat dipahami bahwa semua yang ada di langit dan di bumi berasal dari pencipta yang satu (al-wihdah).

Sekiranya ada di langit dan di bumi tuhan-tuhan selain Allah, tentulah keduanya itu telah rusak binasa. Maka Maha Suci Allah yang mempunyai 'Arsy daripada apa yang mereka sifatkan. (QS. al-Anbiyā [21]: 22).

Terdapat dua aspek dalam tauhīd yang berbicara tentang memelihara keutuhan bumi dan alam semesta. Aspek pertama berbicara tentang esensi dari Keesaan Allah, bahwa Dia tidak memiliki sekutu, bahwa Dia berdiri sendiri, yang diciptakan oleh siapa pun namun adalah Pencipta (al-Khāliq) dan manusia dilarang menentang-Nya dengan bersaing dengan apa pun yang adalah ciptaan-Nya. Kedua, segala sesuatu yang Allah telah ciptakan adalah satu kesatuan yang tidak dapat dipisahkan. Allah memberikan kesempurnaan bagi semua ciptaan-Nya dalam suatu sistem yang terorganisasi dengan baik dan teratur. Semuanya saling terkait, tetapi tidak ada cara bagi manusia untuk memahami segalanya. Sebagai contoh, keutuhan suatu ekosistem didasarkan pada urutan hal-hal yang tidak dapat eksis secara sendiri-sendiri. Ekosistem adalah gabungan dari berbagai spesies, baik itu hewan, tumbuhan, atau mikroorganisme, serta mineral: bendabenda yang dianggap mati namun memberikan roh bagi kehidupan.

Semua hal dalam suatu ekosistem adalah makhluk, ciptaan, dan semuanya bersujud di hadapan Allah, seperti dalam firman-Nya:

Langit yang tujuh, bumi dan semua yang ada di dalamnya bertasbih kepada Allah. Dan tak ada suatupun melainkan bertasbih dengan memujiNya, tetapi kamu sekalian tidak mengerti tasbih mereka. Sesungguhnya Dia adalah Maha Penyantun lagi Maha Pengampun. (QS. al-Isrā [17]: 44).

Oleh karena itu, semua ciptaan Allah tunduk kepada-Nya dengan cara mereka masing-masing. Menurut seorang mufassir Ibn Kasīir, tidak ada makhluk yang tidak bertasbih dan memuji Allah. Namun manusia tidak mengerti bagaimana cara tasbih mereka untuk menyatakan kemuliaan-Nya. Ini berarti bahwa manusia tidak memahami nyanyian mereka, karena mereka semua berbicara dalam bahasa mereka sendiri. Ibn Kaśīr mengutip hadis Nabi saw yang menyatakan bahwa Nabi Muhammad melarang pembunuhan katak, dengan berkata, "suaranya adalah tasbih." Karena itu, bunyi atau suara yang keluar dari makhluk Allah adalah kesaksian tentang keesaan-Nya, dalam 
rubūbiyah (keteraturan) dan Ilāhiyah (ketuhanan) Allah. Ia menandaskan:

"Dalam segala hal adalah tanda, yang menunjukkan bahwa Dia (Allah) adalah satu." 12

Oleh karena itu, perlu dipahami bahwa sebagai bagian dari kesatuan alam semesta, manusia serta unsurunsur lain dari ekosistem alam, semua tunduk dan mematuhi hukum-hukum Allah atau apa yang sekarang kita sebut sebagai hukum alam. Sebagai konsekuensi logisnya, manusia harus menghormati alam. Ini berarti kita tidak boleh melihat alam sebagai objek untuk dieksploitasi dan dirusak, tanpa benarbenar memahami makna, esensi, dan fungsi ekosistem. Kita harus mengupayakan berbagai cara untuk melestarikannya.

Demikian pula, jika asal-usul manusia dihancurkan, maka kekacauan akan muncul, sama seperti hilangnya salah satu unsur dalam sistem yang seimbang sempurna akan mengubahnya menjadi sistem yang tidak harmonis dan kacau.

\section{Khalïfah}

Cendekiawan Muslim, Nurcholis Madjid menulis bahwa ketika Tuhan mengumumkan penciptaan manusia, peristiwa ini terjadi sebagai suatu drama kosmis, sebuah transaksi penciptaan manusia seperti yang digambarkan oleh al-Quran, di mana Allah menempatkan manusia sebagai khalïfah atas bumi.

"Ingatlah ketika Tuhanmu berfirman kepada para Malaikat: 'Sesungguhnya

\footnotetext{
${ }^{12}$ Ibn Kasīir, Tafsir Ibnu Katsir, Jil. V, terj. M. Abdul Ghoffar E.M, Jakarta: Pustaka Imam asy-Sayfi'I, 2001, h. 269-270.
}

Aku hendak menjadikan seorang khalifah di muka bumi.' Mereka berkata: 'Mengapa Engkau hendak menjadikan (khalifah) di bumi itu orang yang akan membuat kerusakan padanya dan menumpahkan darah, padahal kami senantiasa bertasbih dengan memuji Engkau dan mensucikan Engkau?' Tuhan berfirman: 'Sesungguhnya Aku mengetahui apa yang tidak kamu ketahui."' (QS. alBaqarah [2]: 30).13

Madjid menjelaskan bahwa "drama kosmik" yang melibatkan Allah, Malaikat, Manusia, dan Setan terjadi pada lokus primordial yang disebut jannah (taman surga) ini dimulai dengan Allah "mengucapkan" bahwa Ia akan membuat umat manusia sebagai khalifah-Nya atas bumi. Namun para malaikat ragu dan skeptis terhadap kemampuan manusia untuk menjalankan tugasnya, mengingat kecenderungan manusia untuk menghancurkan dan menumpahkan darah. Akan tetapi, klaim para malaikat ini ditolak oleh Allah, karena mereka tidak mengetahui rahasia-Nya untuk mengajar Adam "semua nama". Selanjutnya, Nurcholish Madjid menyatakan bahwa dalam tugasnya sebagai khalifah maka:

1) Martabat manusia berkaitan dengan konsep bahwa alam secara keseluruhan menyediakan kebutuhan manusia, untuk menjadi lahan garapan dan tempat untuk menjalankan tugasnya.

2) Martabat ini juga terkait dengan nilainilai kemanusiaan yang universal.

${ }^{13}$ Nurcholish Madjid, Islam Agama Peradaban: Membangun Makna dan Relevansi Doktrin Islam Dalam Sejarah, Jakarta: Paramadina, 1995, h. 180-181. 
3) Untuk menjalankan tugasnya sebagai khalifah Allah di bumi, manusia dibekali ilmu pengetahuan.

4) Martabat manusia juga dilengkapi dengan kebebasan, dengan pembatasan tertentu (semua kecuali buah dari pohon terlarang dapat dimakan).

5) Setiap pelanggaran atas batas-batas tersebut mendegradasi umat manusia.

6) Dorongan untuk melanggar batas-batas tersebut dinamakan keserakahan, yaitu perasaan yang tak terpadamkan bahwa semua karunia dari Allah tidaklah memadai.

7) Karena ilmu pengetahuan saja tidak menjamin manusia takkan terdegradasi, maka arahan dari Allah diperlukan sebagai jaring pengaman rohani. ${ }^{14}$

Di dalam konsep mengembangkan kehidupan yang bermartabat, spiritualitas sangat penting karena menyediakan alat kendali atas sikap-sikap negatif manusia. Rasa kemanusiaan adalah kekal untuk orang-orang yang mengemban tugas mereka sebagai khalifah, lengkap dengan semua dimensinya. ${ }^{15}$ Pada intinya, status khalifah diberikan kepada manusia agar ia bertindak secara bertanggung jawab dalam pengelolaannya atas bumi.

Dalam mengelola bumi, manusia diharapkan untuk bertindak berdasarkan ilmu pengetahuan dan bukan sekadar keinginan sendiri (QS alNisā [4]: 135, al-Mu'minūn [23]: 71) karena keserakahan akan membawa tidak hanya akibat jangka pendek, yakni kerugian atas kepunahan, tetapi juga berbagai bencana lingkungan. Menipisnya cadangan sumber daya alam dari

\footnotetext{
${ }^{14}$ Nurcholish Madjid, Cita-Cita Politik Islam, Jakarta: Paramadina, 1999, h. 142-143. 15 Ibid.
}

hari ke hari adalah tantangan bagi manusia dan juga sebagai sarana untuk membuatnya sadar bahwa eksploitasi tidak boleh melanggar batas keseimbangan, atau kerusakan akan muncul. Selain itu, manusia diharapkan untuk menjaga janji mereka dan melaksanakan mandat mereka, karena Allah telah berfiman:

Sesungguhnya Kami telah mengemukakan amanat kepada langit, bumi dan gunung-gunung, maka semuanya enggan untuk memikul amanat itu dan mereka khawatir akan mengkhianatinya, dan dipikullah amanat itu oleh manusia. Sesungguhnya manusia itu amat zalim dan amat bodoh. (QS. al-Aḥzāb [33]: 72).

\section{Mīzān (Keseimbangan)}

Mìzān, menurut asal katanya, berarti 'skala' atau 'keseimbangan'. Allah telah memberikan gambaran yang sangat mendasar dalam al-Quran untuk menggambarkan penciptaan langit dan bumi yang seimbang, karena segala sesuatu di alam semesta diciptakan berpasangan (QS. Yā Sīn [36]: 36). Misalnya, siang dan malam, langit dan bumi, panas dan dingin, hujan dan kemarau. Allah berfirman dalam Surat al-Raḥmān [55]: 7-8:

Dan Allah telah meninggikan langit dan Dia meletakkan keseimbangan (keadilan), supaya kamu jangan melampaui batas tentang keseimbangan itu.

Keseimbangan diciptakan oleh Allah melalui gaya-gaya gravitasi konstan yang bekerja pada benda-benda langit, sehingga menjaga planet-planet tetap pada orbitnya masing-masing. Keseimbangan membantu bumi dan 
planet-planet lain dalam tata surya berputar mengelilingi matahari secara konsisten dan tidak berubah-ubah jalurnya. Jadi bumi berputar pada porosnya sendiri, tanpa gangguan bahkan hingga detik ini, karena adanya keseimbangan dan gravitasi yang telah diciptakan Allah.

Apa yang akan terjadi jika gaya gravitasi lebih besar dari apa yang kita alami hari ini? Akan benar-benar sulit bagi kita untuk berjalan, apalagi berlari. Manusia dan semua makhluk akan mengonsumsi lebih banyak energi untuk sekadar berjalan. Apa yang akan terjadi jika gravitasi itu menghilang? Debu dan semua partikel, termasuk sampah dan ranting dan segala sesuatu akan mengapung di udara dan kita akan merasa sangat sulit untuk bernapas di permukaan bumi. Kecepatan hujan akan berkurang secara drastis dan bahkan airnya mungkin menguap sebelum menyentuh permukaan bumi. Sungai akan mengalir sangat lambat dan itu akan sangat sulit untuk menghasilkan listrik dari sungai, seperti yang kita mampu lakukan hari ini. ${ }^{16}$ Oleh karena itu, Allah telah menetapkan standar yang sangat tepat.

Sesungguhnya Kami menciptakan segala sesuatu menurut ukuran." (QS. al-Qamar [54]: 49).

Ketepatan dan akurasi memastikan keseimbangan dalam kehidupan di bumi, dan seperti Allah menciptakan dunia menurut keseimbangan, ajaran Islam juga didasarkan pada keseimbangan dan keadilan. Bahkan pikiran dan hati nurani manusia

16Lihat: Harun Yahya, Design in Nature. London: Taha Publisher, 2002. diciptakan selaras dengan ajaranajarannya. Oleh karena itu, orang tidak boleh bersandar terlalu jauh ke kanan atau ke kiri, melainkan berusaha untuk mencapai keseimbangan dalam semua aspek kehidupan.

Sehubungan dengan upaya konservasi, gagasan keseimbangan telah sangat diprioritaskan dan dievaluasi. ${ }^{17}$ Berbagai fenomena yang merusak, seperti tanah longsor, banjir, angin puting beliung, dan bahkan perubahan iklim saat ini, dianggap sebagai akibat langsung dari ketidakseimbangan.

Ketika kawasan hutan dan lahan dengan kemiringan yang ekstrem ditebang pepohonannya untuk dibuka sebagai lahan bercocok tanam, mereka menjadi tidak stabil, menyebabkan tanah longsor. Banjir terjadi karena lahan yang berhutan sekaligus bertindak sebagai spons untuk mempertahankan air pada musim hujan, apabila rusak tidak dapat lagi menyimpan air di dalam tanahnya. Perubahan iklim terjadi karena atmosfer semakin tebal dari hari ke hari dengan gas rumah kaca yang dikeluarkan oleh aktivitas manusia, termasuk namun tidak terbatas pada karbon dioksida $\left(\mathrm{CO}_{2}\right)$ dari kendaraan berbahan bakar fosil dan industri.

Albert Gore mencatat bahwa manusia melepaskan 90 juta ton $\mathrm{CO}_{2}$ setiap harinya. Untuk menyeimbangkan hal ini, hutan (dan juga lautan) mampu menyerap emisi tetapi akan memakan

${ }^{17}$ Albert Gore, Our Choice: Rencana untuk Memecahkan Krisis Iklim, terj. P. Handono Hadi, Jakarta: Kanisius, 2010; J. Rockström, et al, "A Safe Operating Space for Humanity", dalam Nature 461 (24 September 2009), h. 472-475. 
waktu dari 30 sampai 1.000 tahun untuk melakukannya. Oleh karena itu, pemanasan global secara langsung disebabkan oleh gangguan oleh manusia terhadap keseimbangan, melalui pencemaran udara dengan gas rumah kaca. Gangguan terhadap keseimbangan dengan demikian disebut gangguan antropogenik, atau yang disebabkan oleh manusia. ${ }^{18}$

\section{Fitrah}

Fițrah secara harfiah berarti 'asal', 'keaslian', atau 'keadaan alami'. Definisi yang tepat dari fițrah adalah "keadaan alami atau naluri yang ditemukan dalam manusia, binatang atau sesuatu yang memaksa manusia atau makhluk mendambakan keadaan tersebut."

Umat Islam meyakini bahwa semua manusia dilahirkan sebagai Muslim dan dalam keadaan murni. Seorang bayi lahir murni, tanpa ada dosa dan dilahirkan dalam fitrah, sebagaimana tidak ada yang mengintervensi kelahirannya. Jika seorang bayi meninggal, ia mati dalam kemurniannya. Oleh karena itu, apakah seseorang menjadi religius atau tidak bergantung pada bagaimana orang tua mereka mendidik mereka setelah itu.

Jadi, fitrah, dalam hal ini, adalah pengetahuan, di mana sejak Allah menciptakan umat manusia, mereka telah diakui oleh-Nya. Dalam all-Quran, kata fițrah ditemukan dalam ayat berikut:

Maka hadapkanlah wajahmu dengan lurus kepada agama Allah; (tetaplah atas) fitrah Allah yang telah menciptakan manusia menurut fitrah itu. Tidak ada perubahan pada fitrah Allah. (Itulah) agama yang lurus;

18Ibid. tetapi kebanyakan manusia tidak mengetahui." (QS. al-Rūm [30]: 30).

Menurut Ibn Kasīir, manusia seharusnya mengikuti fițrah yang telah Allah berikan kepada semua makhluk. Allah telah menganugerahkan fitrah bahwa Dia adalah Satu, bahwa tidak ada Allah lain (ilāh) yang benar (Haq) selain Dia. Ia lebih lanjut menambahkan pernyataan bahwa "tidak ada perubahan dari fitrah Allah", yang berarti bahwa manusia tidak boleh mengubah ciptaan Allah, ataupun mengubah fitrah manusia yang telah diberikan oleh Allah kepada manusia. Ini berarti bahwa Allah membuat semua ciptaan-Nya dengan menganugerahkan atas mereka fitrah yang sama, di mana tidak ada perbedaan antara satu manusia dengan yang lainnya. ${ }^{19}$ Yasin Mohammed (1996) kemudian mendefinisikan fițrah sebagai berikut:

"Konsep fitrah sebagai kebaikan yang asli, dalam pandangan saya, tidak hanya berkonotasi dengan penerimaan pasif untuk bertindak baik dan benar, tetapi kecenderungan aktif dan kecenderungan bawaan alamiah untuk mengenal Allah, untuk tunduk kepada-Nya dan melakukan yang benar. Ini adalah kecenderungan alamiah manusia, dengan tidak adanya faktor-faktor yang sifatnya berseberangan. Meskipun semua anak dilahirkan dalam keadaan fitrah, pengaruh lingkungan sangat menentukan; orang tua dapat mempengaruhi agama anak dengan membuatnya seorang Kristen, Yahudi atau Magian. Jika tidak ada pengaruh buruk, maka anak akan terus memanifestasikan

${ }^{19} \mathrm{Ibn}$ Kas̀īr, Tafsir Ibnu Katsir, Jil. VI, terj. M. Abdul Ghoffar E.M, Jakarta: Pustaka Imam asy-Sayfi'I, 2001, h. $371 .$. 
fițrah-nya sebagai sifat sejatinya. Karena banyak bayi dilahirkan dengan cacat fisik kotor, pencederaan sebagaimana dimaksud dalam hadis ini tidaklah dimaksudkan dalam arti fisik, artinya semua anak dilahirkan secara rohani murni, dalam keadaan fitrah. Referensi kepada hewan yang lahir utuh dalam hadits yang inti harus dilihat sebagai analogi untuk menggambarkan kondisi keutuhan rohani yang serupa saat seorang anak dilahirkan." 20

Dengan demikian, fițrah dalam konteks ajaran Islam terhadap lingkungan berarti bahwa Allah ingin manusia memegang teguh janjinya sesuai dengan fitrah Islam. Ajaranajaran Islam memberikan batas-batas moral yang pada intinya menetapkan bahwa tidak ada yang boleh dilakukan secara berlebihan, apalagi untuk menciptakan kehancuran (QS. Ali Imran [3]: 147; al-Mā'idah [5]: 77; al-An'ām [6]: 141; al-A'rāf [7]: 31).

\section{E. Penutup}

Dari uraian di atas dapat ditarik kesimpulan sebagai berikut:

1) Islam mengajarkan keterpaduan, tidak ada dikotomi antara pengetahuan (sains) dengan keyakinan agama.

2) Allah swt memberikan karunia, dan memberikan Qur'an dan Sunnah sebagai pedoman dalam pengelolaan bumi.

3) Memelihara alam dan lingkungan merupakan bagian dari misi khalifah (pengemban amanah).

20Mohammed Yasien, The Definition of Fitrah, London: TA-HA Publishers, 1996, h. 21.
4. Memelihara dan menjaga keseimbangan (mīzōn) bumi, merupakan wujud dari amanah agar manusia tetap berada dalam fitrahnya. []

\section{Daftar Pustaka}

Bakar, Osman, Tauhid dan Sains: Esaiesai tentang Sejarah dan Filsafat Sains Islam, terj. Yuliani Liputo, Bandung: Pustaka Hidayah, 1994.

Gore, Albert, Our Choice: Rencana untuk Memecahkan Krisis Iklim, terj. P. Handono Hadi, Jakarta: Kanisius, 2010.

Ibn Kasīr, Tafsir Ibnu Katsir, Jil. II, V, dan VI, terj. M. Abdul Ghoffar E.M, Jakarta: Pustaka Imam asy-Sayfi'i, 2001.

Khalid, Fazlun, Qur'an Creation and Conservation, Birmingham, UK: Islamic Foundation for Ecology and Environmental Sciences 1999.

Madjid, Nurcholish, Islam Agama Peradaban: Membangun Makna dan Relevansi Doktrin Islam Dalam Sejarah, Jakarta: Paramadina, 1995.

Madjid, Nurcholish, Cita-Cita Politik Islam, Jakarta: Paramadina, 1999.

Mangunjaya, Fachruddin, "Islam and Natural Resources Management", dalam J.M. McKay (ed), Integration Religion Within Conservation: Islamic Belief and Sumatran Forest Management, UK: Darwin Initiative Case Study, Durrel Insitute of Conservation and Ecology University of Kent, 2013.

Murdiarso, D., "Perubahan Iklim: Dari Obrola Warung Kopi ke Meja Perundingan", Prisma, April 2012.

Nasr, Seyyed Hossein, "The Problem," taken from Man and Nature, Chicago: Kazi Publication, 1997. 
Rockström, J., et al, "A Safe Operating Space for Humanity", dalam Nature 461 (24 September 2009).

White Jr, Lynn, "The Historical Root of our ecologic crises", Science Vol 155 (Number 3767), 10 Maret 1967.

Wikipedia.org/wiki/Maurice_Bucaille Yahya, Harun, Design in Nature. London: Taha Publisher, 2002.

Yasien, Mohammed, The Definition of Fitrah, London: TA-HA Publishers, 1996. 